\title{
Observations on Intra-Nebular Kyara Among Youth
}

\author{
Fumiaki SENUMA \\ Bunri University of Hospitality, Japan \\ fumiakisenuma@hotmail.com
}

\begin{abstract}
This article summarizes the author's book (Senuma, 2007) on kyara in communication among young people in modern Japan, and subsequent research developments.

Here, kyara refers to an intelligible, stereotypical abstraction, derived from a person's prominent traits. Among the young generation, individuals are sometimes assigned a specific kyara by others in their peer group, regardless of that individual's intentions. Accepting and performing that kyara can elevate the mood of the situation, and become the occasion for communication and humour. This is a benefit of kyaras, but they have disadvantages as well. For example, it may be burdensome to perform that kyara, they might not like the kyara assigned by their friends, or they may be troubled by the disconnect between kyara and self. If kyara-based teasing turns into bullying, this can be a source of suffering for youths as well.

The above trends have escalated since the publication of Senuma (2007). Situations in which young people should perform kyaras around their friends have increased. Moreover, the younger generation must increasingly use different kyara for different situations due to the popularization of smartphones and the ubiquity of various social networking sites.

This "situational use of different selves" is contrary to the identity theory, which posits that people build a consistent self during adolescence. Human relationships and types of friendship are inherently varied, but to the young, fear of losing friends takes precedence, so they perform kyaras to fit in with their friends. If they become too accustomed to performing these kyaras, their innate right to change within their relationships to others could be stripped away by the group dynamic.
\end{abstract}

Keywords: kyara (the role); Japanese youth; fitting into society; multiple kyaras

\section{Povzetek}

Članek povzema avtorjevo knjigo (Senuma, 2007) o t.i. kyara ali vlogah v komunikaciji med mladostniki in sedanji Japonski družbi ter o razvoju raziskav po njeni publikaciji.

$\checkmark$ članku se kyara nanaša na jasno stereotipično abstrakcijo, ki naj bi izhajala iz najbolj izstopajočih značilnosti neke osebe. Mladostniki posamezniku v svojem krogu določijo neko vlogo ne glede na posameznikove namere $v$ tistem krogu. $S$ sprejetjem in izvajanjem dodeljene vloge posameznik izboljša vzdušje med vrstniki in spodbudi medsebojno komunikacijo ter humor. To so zagotovo prednosti igranja vlog, vendar pa ima takšno vedenje tudi slabe plati. Na primer, nekaterim posameznikom je lahko igranje dodeljene vloge $v$ breme, nekateri pa ne najdejo povezave med 
vlogo, ki jo igrajo, in med dejanskim sabo. Poleg tega lahko posmeh, ki ga je deležen posameznik ob igranju neke vloge, preide $v$ psihično nadlegovanje.

Pojavnost zgoraj omenjenih značilnosti se je po publikaciji avtorjeve knjige še močno povečala. Situacije, v katerih so posamezniki primorani igrati dodeljene vloge, so se pomnožile. Še več, mlajše generacije so $s$ širjenjem pametnih telefonov in $z$ uporabo številnih spletnih socialnih omrežij primorane igrati tudi več različnih vlog hkrati.

Takšna situacijska raba različnih vlog samega sebe je v nasprotju s teorijo identitete, ki zagovarja tezo, da se karakter osebe izoblikuje $v$ najstniških letih. Človeški odnosi in prijateljstva so že $v$ osnovi zelo raznolika in mladi $v$ strahu pred izgubo kakšnega ustvarjenega prijateljstva igrajo različne vloge, takšne, ki ustrezajo pričakovanjem posameznega prijatelja. $\mathrm{S}$ tem, ko posameznik zaradi družbe preveč prevzame igranje vlog, izgubi notranji občutek o pravici do svobodnega obnašanja.

Ključne besede: kyara (lik, vloga); japonska mladina; prilagajanje družbi; mnogotere vloge

\section{Introduction}

This article summarizes the author's book (Senuma, 2007) on kyara in communication among young people in modern Japan, and its subsequent research developments. At Japanese schools, rather than speaking to just anyone, students tend to belong to small, closed groups of 2 to 4 , and communicate exclusively within those groups. The sociologist Shinji Miyadai called this trend, which began in the 80s, "nebularization" (Miyadai, 1994). The title of this article derives from Miyadai's idea.

In the author's early 20s, the author was working as a comedian for the largest entertainment producer in Japan. The dogma of that time in the entertainment industry was that one could appear on television frequently as long as one created a unique kyara. Although the author desperately searched for his own kyara, he came up against various limits and ended up quitting the entertainment business. While working in entertainment, the author was also conscious of kyara in everyday communication with the author's non-entertainer friends at the university.

After graduation from university the author entered a graduate school to research humor. Actively engaging in youth communication to do his research, he found out that kyara-mediated communication and relationships have become even more pervasive than when the author had been working as an entertainer. For his master's thesis the author performed fieldwork on kyaras among young people ${ }^{1}$ and organized the results into a research paper. Later, the author rewrote his thesis and in 2007 published a book named Kyararon or "Character theory".

\footnotetext{
${ }^{1}$ The fieldwork referred to here is an interview survey on kyaras conducted in September and October 2005 for the author's master's thesis, "Kyara to iu Na no Kosei" (characteristics of the label kyara). The survey subjects consisted of 95 people in 28 groups, male and female, aged 15 to 25 , in Tokyo and its suburbs. Kyararon is based on this survey.
} 
In this article, the author will firstly re-organize and summarize Kyararon based on his experiences and position. Then, the author will consider youth kyara trends since the publication of Kyararon, and point out some problems involved.

The word kyara has various meanings, however, the author will in this article only focus on those observed in human relationships among small groups of the younger generation, like those described in Kyararon.

\section{Synopsis of Kyararon}

The word kyara, as examined in Kyararon, has been in use among young people from around 1999 onward and referred to one's own and one's peers' personalities and characters within a school setting; e.g. the "scatterbrained kyara", who often leaves out important details when speaking, the "serious kyara," whose words and actions are always deliberate, and the "poisoned-tongue kyara", who often speaks ill of others. Kyararon considers kyara in terms of the relationship between "stereotypes," "roles," "performance," and "individuality." This will be explained below in summary.

First, in the opinions of the youths themselves, a kyara is an intelligible, stereotypical abstraction, derived from a person's prominent traits. Young people derive their own and their friends' kyaras from physical characteristics, appearance, clothing, personality, abilities, and manner of speaking. However, most of them say that they themselves do not know their own kyaras.

Mori's (2005, p. 89) thoughts on kyara and role are of reference here. He points out that kyaras function as "roles" or "typecasts" within groups, and constitute a division of roles/labor enabling the members to spend time together enjoyably. In the author's own fieldwork as well, it was clear that among the younger generation, accepting and performing a kyara can elevate the mood, become the occasion for communication, and create humor.

A kyara is a label assigned to individuals by others in their peer group, regardless of that individual's intentions. As this label is obstinate once affixed, the individual must behave in compliance with it, even if he/she does not like it. In other words, there is a performative component to kyaras. However, some individuals are not aware of this.

Doi's (2004, p. 2009) ideas on kyara and personal qualities are useful here. According to him, a kyara is not a personal quality that one discovers by comparing oneself to others, nor some kind of internal selfness that one searches for like a diamond. Rather, he says, kyaras are conferred by others, they must not be redundant within the same peer group, and are composed of minute differences with others. That is, among the young subjects studied, a kyara is a tool for elevating the mood and creating humor enjoyed by all, while simultaneously being a safe space for the self and defense mechanism against teasing. 
Although kyaras have the above benefits, they clearly have downsides as well. For example, the youths may feel it burdensome to perform their kyaras. They might not like the kyara assigned by their friends, or be troubled by the disconnect between kyara and self. It was also found that kyara-based teasing can turn into bullying and be a source of suffering for them as well.

\section{When excessive acting becomes normal: relationships among the young}

Having looked at the reality of kyaras among youths, we will next discuss developments since Kyararon was published in 2007. To sum up the author's conclusions, now as before the younger generation is conscious of kyaras, and their communication is predicated on them. The good and bad aspects the author discussed in 2007 are as present as ever. The basis for saying this comes from Chishima/Murakami (2015). They performed empirical psychological research on youths to clarify the actual state of and attitudes toward kyaras. Furthermore, the author also found these trends in the author's own participant observations, fieldwork, and casual conversations with students.

If there has been a change in youth kyara awareness since then, it would be that the performance of kyaras is becoming increasingly normal. For instance, in the survey conducted every few years by the Japan Youth Study Group, the number of youths who responded affirmatively when asked if they "consciously use a different self depending on the situation" increased from $43.2 \%$ in 2002 to $49.5 \%$ in $2012^{2}$.

Another study worth noting is the survey on "reading the [social] atmosphere" (kuuki wo yomu) conducted by the National Federation of University Co-operative Associations (National Federation of University Co-operative Associations, 2008, p. 53). When asked whether they felt worried about reading the social atmosphere around them, $81 \%$ of male and $85 \%$ of female participants responded that they were "worried" or "somewhat worried". Of course, the "atmosphere" which these youths are worried about contains diverse elements. Even so, considering how they nonassertively try to fit in with those around them, the act of showing their true selves could be interpreted by their friends as an inability to read the atmosphere. If that is the case, this survey data indicates that large numbers of young people are conscious of acting for the benefit of those around them.

In the Warai ni Kansuru Anketo Chosa ("Questionnaire on humor" in English) that the author conducted in 2015, there was a question of whether they laugh to be polite, or force themselves to laugh in daily life. The author asked university students

\footnotetext{
${ }^{2}$ This questionnaire was conducted in Tokyo and Kobe, and administered to a 2-strata randomized sample, ages 30 to 49, chosen from the Basic Resident Register. 4200 questionnaires were distributed with a response rate of 1050 for aged 16 to 29, and 719 for aged 30 to 49 . http://jysg.jp/img/flash20130724.pdf (Last accessed October 31, 2015)
} 
to select a number from 1 to $4^{3}$ as their answer; 68\% answered with 3 or 4 , which were affirmative answers. Moreover, when asked whether they ever pretend to enjoy a friend's joke to avoid ruining the mood, 59.2\% responded affirmatively, with 3 or 4 . These results show that rather than being their "natural selves," university students try to fit in with those around them.

Harada (2010), who works for an advertising agency and researches youths from the perspective of marketing, has formulated nine the so-called "rules" for groups of young people based on his extensive fieldwork. For example, they should produce polite laughter, encourage downtrodden locals, and use "da yo ne" (used to indicate or elicit agreement) in conversation. Breaking these rules could make one get expelled from the group and ostracized. The existence of such rules strongly indicates an attitude of wanting to fit in with others.

Judging by these survey results and opinions, it would seem that there is an increasing number of occasions in which youth must play a kyara among their friends ${ }^{4}$. Author's concern about it is that if acting becomes extremely de rigueur in daily life, it will become the new "natural."

Human relationships and types of friendship are inherently varied, and the freedom to change oneself in the context of one's relationship to others is a universal right. But to the young, fear of losing friends takes precedence, so they perform kyaras to fit in. If they become too accustomed to performing their kyaras, their innate human right to change within their relationships to others could be stripped away by the group dynamic.

\section{The proliferation of situational kyaras}

Now the author will discuss another thing that has changed since Kyararon. As a reference the author will use Dentsu Inc.'s "Wakamono Maruwakari Chosa 2015" (Engl. "A comprehensive survey of young people") ${ }^{5}$. According to this survey, the younger generation uses many selves depending on the situation; the average

\footnotetext{
${ }^{3}$ This survey was conducted in January 2015 together with Hiroyuki Aoto from the Bukkyo University's Department of Education. The survey contained 43 questions on humor to 206 male and female university students from the Kanto and Kansai regions. The students selected the number of the answer on a scale of 1 ("never") to 4 ("often") that best applied to them.

${ }^{4}$ Doi (2014: 71) has raised this point as well. He argues that the soto-kyaras (external kyaras) that people perform to fulfill the expectations of others are expelling their simpler, individualistic uchikyaras (internal kyaras), and that the era of self-searching has passed, while the pursuit of friends has become the mainstream.

${ }^{5}$ Dentsu Inc. "Wakamono Maruwakari Chosa 2015". http://www.dentsu.co.jp/news/release/pdfcms/2015038-0420.pdf (Last accessed September 8, 2015) This was a survey of youth values and communication awareness, conducted on the Web in February 2015 and administered to 3000 male and female youths (unmarried, high school students and older; ages 15 to 29) from the Kanto, Kansai, and Tokai regions.
} 
numbers of kyaras used in daily life are as follows: 5.7 for high school students (male: 4.9, female: 6.6), 5.0 for university students (male: 4.2, female: 5.8 ), and 4.0 for working adults in their twenties (male: 3.2 , female: 4.8 ).

The context for this is the popularization of smartphones and concurrent ubiquity of various social networking sites among young people. For example, they feel connected with other students on Facebook, Twitter, etc. even if they're not physically in the same school. Once a friend, it is easy to stay connected and at the same time difficult to break the connection. So perhaps the number of kyaras each person has is equal to the number of human relationships that he or she has built.

With regards to Twitter, according to the same Dentsu Inc. survey, high school students have an average of 3.1 Twitter accounts, while university students have 2.5. When I asked students at the university where I work about these multiple accounts, they responded that it was normal to have 2 or 3 accounts, each for tweeting with a different kyara. Some students had as many as 10 accounts, which they use situationally. These multiple accounts might be used, depending on the account, for complaining, tweeting about interests the user does not want to talk about with others, or even as joke accounts. Some students say they try to play the role of a good person on their main account. Thinking about this from the angle of kyaras, it seems they are using abusive kyaras, otaku kyaras, or good person kyaras depending on the situation. To the younger generation, each account on the Internet is another of their kyaras.

Given the situation on the Web, one wonders exactly how many kyaras young people are using. There is quite a diversity of locations where they perform situational kyaras, e.g. among local and school peers, school clubs, friends, part-time work, cram schools, and prep schools. Added to these are multiple Twitter accounts, Facebook, and mobile games where they communicate by playing the "upstanding hero kyara", or the "weak and always in need of saving kyara," etc.

Moreover, not a few young people regard kyaras as tactics to be deployed on certain occasions to fit the circumstances - e.g. one kyara for the first date, another for a job interview, etc. Considering this, one can see that they have a fairly large number of situational kyaras. Can we be certain that the situational use of multiple kyaras poses no problems whatsoever?

\section{Conclusion}

It appears that this "situational use of different selves" is contrary to identity theory, which posits that people build a consistent self during adolescence. A question whether there are no problems with continually performing multiple selves evokes a theme that would demand some further thoughts from a variety of perspectives but 
this article will stop at the following three criticisms that are limited to friendships among the young, based on the above ideas ${ }^{6}$.

1. If youths use different selves depending on the group, there is a problem of which kyara they should prioritize when it is necessary to deal with two groups simultaneously. No matter which kyara is prioritized, at least one of the groups will feel uneasy that their friend's kyara is suddenly different from the usual. This different-from-usual otherness could cause trust problems.

2. If the situational use of other selves becomes excessive, there is a concern that young people will lose track of their own sense of self. If this happens, their own strengths and outstanding characteristics will always be dependent on others. In order to maintain self-confidence, they will forever have to fraternize with people who are in some way less capable than themselves. Such selective human relationships would likely inhibit their own potential.

3. Trying to fit in with others is, in a sense, a form of consideration. However, if youths are constantly distracted by the need to be considerate and feel the pressure to always fit in with others, they may lose the ability to make decisions for themselves. This cannot be called freedom. They will be forced to live their lives as "non-entities," always looking to others.

Overcoming this third point is not an easy step. The reason for this is that there is a strong pressure to fit in and conform in Japanese society, as is often pointed out in Japanese cultural studies and illustrated concisely by the Japanese saying "the nail that sticks up gets hammered down." Put another way, this could probably be called a "village mentality" or "collectivism." This characteristic of "fitting in with others" can be read into every aspect of communication among the kyaras of the younger generation.

But what are the commonalities and differences of Japanese culture and kyaras? If there are many commonalities, it is because today's youth has inherited a past culture. Considering this, the use of many situational selves is not entirely problematic. It can be seen as a tool, based on past culture, that the younger generation uses to survive in this current society, with its complex and troublesome human relationships. Skillfully adapting to the situation, they will probably find solutions to the problems raised in this article, too.

Even so, the author strongly believes that engaging in a search for their own kyara, as the author did when working in the entertainment industry, would surely be of help to them in terms of their self-understanding and their way of thinking.

\footnotetext{
${ }^{6}$ Asano (2013), a sociologist, has also pointed out these issues. He expansively considers the problems with the situational use of multiple selves in terms of economics, politics, and ethics. For this reason, the author has limited himself to specific problems from the perspective of the younger generation.
} 


\section{References}

Asano, T. (2013). "Wakamono" towa dareka. Tokyo: Kawade Shobo Shinsha.

Chishima, Y., \& Murakami, T. (2015). Gendai seinen niokeru "kyara" o kaishita yuujinkankei no jittai to yuujinkankei manzokudo no kanren: "kyara" nitaisuru kangaekata o chuushinni. Seinen Shinrigaku Kenkyu, 26 (2), -.

Doi, T. (2004). "Kosei" o aorareru kodomotachi: Shinmitsukenno hen'yo o kangaeru. Tokyo: Iwanami Shoten.

Doi, T. (2009). Kyara-ka suru/sareru kodomotachi: Haijogata shakai niokeru aratana ningenzou. Tokyo: Iwanami Shoten.

Doi, T. (2014). Tsunagario aorareru kodomotachi: Nettoizonto ijimemondaio kangaeru. Tokyo: Iwanami Shoten.

Harada, Y. (2010). Chikagorono wakamonowa naze damenanoka. Tokyo: Kobunsha.

Miyadai, S. (1994). Seifuku shojotachino sentaku. Tokyo: Kodansha.

National Federation of University Co-operative Associations in Japan. (2008). Campus Life Data 2007.

Mori, S. (2008). Nihonwa naze isakaino ooi kunini nattanoka. Tokyo: Chuoukouronsha.

Senuma, F. (2007). Kyararon. Tokyo: Studio Cello. 